\title{
Morphologic Aspects of Abductor digiti minimi Muscle in the Hand
}

\author{
Aspectos Morfológicos del Músculo Abductor del Dedo Mínimo de la Mano \\ "Luiz Carlos Buarque de Gusmão; **Mario Jorge Frassy Feijó \& **** Célio Fernando de Sousa-Rodrigues
}

GUSMÃO, L. C. B.; FEIJÓ, M. J. F. \& SOUSA-RODRIGUES, C. F. S. Morphologic aspects of Abductor digiti minimi muscle in the hand. Int. J. Morphol., 23(4):373-376, 2005.

SUMMARY: The Abductor digiti minimi muscle, and the other hypotenar muscles, frequently presents anatomical variations. According to literature, this muscle can be composed by one, two or three muscular beams, as well as it can present accessory muscular beams.

In dissecations of 40 formolized hands, we objectified to study the morphology and variations of the Abductor digiti minimi muscle. The muscle presented two muscular beams in $82,5 \%$, three beams in $15 \%$ and only 1 beam in $2,5 \%$ of the cases. In none of cases accessory muscular beams were observed.

When compared with literature, are observed statistics difference in some studied aspects. The results found in the research allow to affirm that the Abductor digiti minimi muscle is formed by two muscular beams in the biggest part of the cases. The division of the muscle in three muscular beams is common of being found.

KEY WORDS: Anatomy; Hand; Abductor digiti minimi muscle; Muscles.

\section{INTRODUCTION}

Anatomical literature describes cases of ulnar nerve compression in the fist caused by anomalous hypothenar muscles (Harvie et al., 2003). The Abductor digiti minimi muscle is part of this group and frequently presents anatomical variations, in its morphology and proximal and distal insertions (Netscher \& Cohen, 1997; Harvie et al., 2004).

It is cited at the anatomical literature that the Abductor digiti minimi muscle can be composed by one or more muscular beams (Williams et al., 1995; Murata et al., 2004), being more found presenting only one beam, as described by Testut (1911) and schematized in pictures by other authors (Grant, 1948; Testut \& Latarjet, 1959; Gray, 1977; Lockhart et al., 1983; Woodburne, 1984). However, some authors cite the division in two portions as very frequent (Neto et al., 1984; Gardner et al., 1971; Williams et al.; Murata et al.).
According to Neto et al. the two muscular beams appear joined, in its proximal insertion on the pisiforme bone, and they are separated in its extension, well delimited, receiving the denomination, suggested by these authors, of lateral muscular beam, the most superficial, and medial muscular beam, the deepest.

Testut affirms to exist a small muscular fascicle that leaves the deep face of Abductor digiti minimi muscle to fix itself to the glenoid ligament of the metacarpofalangeal joint of the minimum finger, characterizing it as an accessory muscular beam. Other authors also relate the existence of accessory Abductor digiti minimi muscle (Sañudo et al., 1993; Netscher \& Cohen; Curry \& Kuz, 2000).

This study objective to verify morphologic aspects of abductor digiti minimi muscle in brazilian individuals.

" Profesor del Departamento de Morfologia de la Universidade Federal de Alagoas. Magister y Doctor en Anatomía Humana. Miembro Titular del Colegio Brasileiro de Cirujanos, Brasil.

*** Monitor de la Disciplina de Anatomía Humana de la Universidade Federal de Alagoas, Brasil.

**** Profesor del Departamento de Morfología de la Universidade Federal de Alagoas. Magíster y Doctor en Anatomía Humana. 


\section{MATERIAL AND METHOD}

Were dissected forty specimens of right and left hands obtained from formol-fixed adult cadavers, of varied ethnic groups and age bands. The dissecations were realized with the aid of a microscope to an increase of $6 x$.

\section{RESULTS}

The Abductor digiti minimi muscle, in 33 cases, was composed by two muscular beams, a lateral and a medial one.
The two beams were well-defined, separated by Areolar connective tissue, and fused togheter in their proximal extremity, without any comunication after their proximal insertion and each one had its proper tendon of distal insertion. Fig. 1.

In 6 cases, the Abductor digiti minimi muscle was composed by three muscular beams. The two bigger portions correspond to the ones decribed previously; the third portion was thin and short in comparison to the other beams, was located deeply to the medial portion, over the opponent digiti minimi muscle. Fig. 2.

In 1 case, the abductor digiti minimi muscle was formed by only one muscular beam.
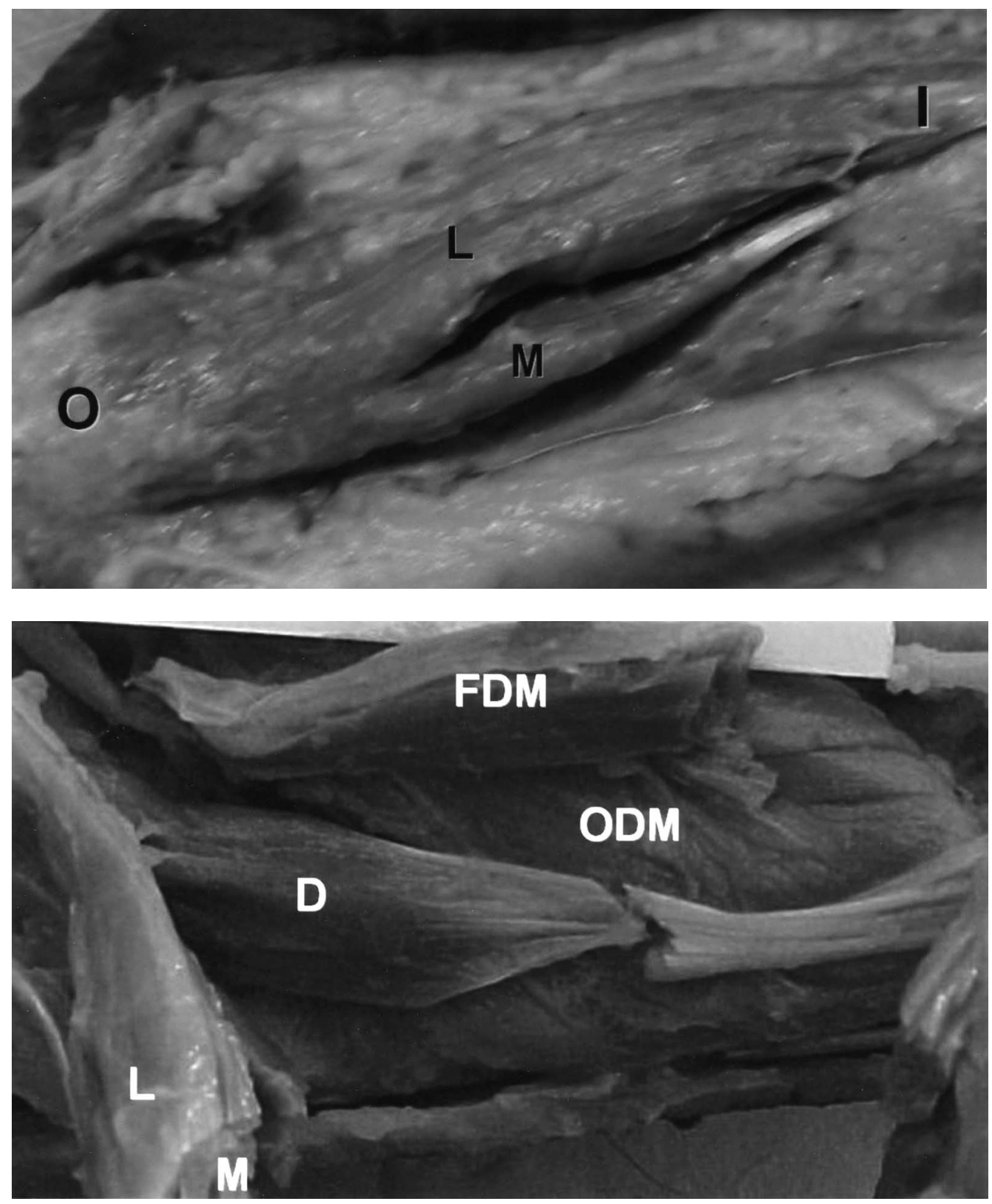

Fig. 1. Ulnar view of the division of Abductor digiti minimi muscle in two beams, lateral (L) and medial (M): Perceie their origin, together, and separated insertion. O. Origin; I. Insertion.
Fig. 2. Abductor digiti minimi muscle composed by 3 muscular beams. Perceive the origin of the deeper muscular beam (D) together to other Abductor digiti minimi muscular beams (L \& M) and its separated insertion tendon. FDM - Flexor digiti minimi muscle; ODM. Opponent digiti minimi muscle. 


\section{DISCUSSION}

Anatomical literature is controversial when affirming by how many muscular beams the Abductor digiti minimi muscle in the man is composed. Analyzing literatures cited in the introduction of this article, in accordance with the different authors, we perceive that the muscle can be composed by one, two or three muscular beams. When comparing these authors with our results, we perceive that a standard was more found: the muscle was divided in two muscular beams in $82,5 \%$ of the cases. With these results, we can disagree with the authors who cite the Abductor digiti minimi muscle formed by only one muscular beam.

Between the searched authors, only Neto et al. confer a nomenclature to these muscular beams, calling medial the deeper muscular beam, located over the opponent digiti minimi muscle, and lateral the other muscular beam, more superficial, responsible for the arch in the ulnar edge of the hand. This nomenclature is considered by us adjusted. Not only to the cases where the muscle has only two, but also to the cases where it presents three muscular beams, when we perceive that the two bigger muscular beams correspond to both above cited.

Also we agree to Williams et al. and Murata et al. authors who relate the existence of the Abductor digiti minimi muscle with 3 muscular beams, because we found 6 cases
$(15 \%)$ with this profile, what shows that also is common the division in 3 beams. Testut affirms that in these cases, this small deep beam that forms the third portion is an accessory beam, of frequency not very rare; we disagree with this information, because this muscular beam has a common origin with the other two muscular beams, a seemed macrocospic structural aspect and a proper insertion; we believe that it is a possible variant presentation of the Abductor digiti minimi muscle, until certain point common of being found, formed by three muscular beams, each one with its proper insertion: two correspondents to the previously described for the muscle, with only the two portions, and a third beam, deep to the others two. We suggest the name deep muscular beam of Abductor digiti minimi muscle to this structure, which we will make reference in this way.

The existence of accessory abductor digiti minimi muscle described by Sañudo et al., Netscher \& Cohen and Curry \& Kuz was not found in our results.

We believe, that the normal composition to the Abductor digiti minimi muscle is to be formed by two muscular beams with proper distal insertions, having to be classified as a bitail muscle. Can be found cases where the muscle presents one or three muscular beams, that occur in lesser frequency.

GUSMÃO, L. C. B.; FEIJÓ, M. J. F. \& SOUSA-RODRIGUES, C. F. S. Aspectos morfológicos del músculo abductor del dedo mínimo de la mano. Int. J. Morphol., 23(4):371-374, 2005. Int. J. Morphol., 23(4):373-376, 2005.

RESUMEN: Tanto el músculo abductor del dedo mínimo como los otros músculos hipotenares presentan frecuentemente variaciones. De acuerdo con la literatura, el músculo abductor del dedo mínimo puede estar compuesto por uno, dos o tres vientres musculares, como también puede presentar cabezas accesorias.

Fueron disecadas 40 manos de cadáveres formolizados, para verificar la morfología del músculo abductor del dedo mínimo y sus variaciones. El músculo presentó dos cabezas musculares en el 82,5\%, tres cabezas en el 15\% y solamente una cabeza en el 2,5\% de los casos. No se observaron cabezas musculares accesorias.

Hubo diferencias estadísticas al comparar las observaciones registradas del músculo, con los datos de la literatura. Los resultados encontrados en esta investigación afirman que el músculo abductor del dedo mínimo de la mano está formado por dos cabezas musculares, en la mayoría de los casos. Es frecuente encontrar un músculo abductor del dedo mínimo compuesto por tres cabezas.

PALABRAS CLAVE: Anatomía; Mano; Músculo abductor del dedo mínimo; Músculos.

\section{REFERENCES}

Curry, B. \& Kuz, J. A New Variation of Abductor Digiti Minimi Accessorius. J. Hand Surg., 25:585-7, 2000.
Gardner, E.; Gray, D. J. \& O’rahilly, R. Anatomia: Estudo Regional do Corpo Humano. $3^{\mathrm{a}}$ ed. Rio de Janeiro, Guanabara Koogan, 1971. 
Grant, J. C. A Method of Anatomy: Descriptive and Deductive. $4^{\mathrm{a}}$ ed. Baltimore, The Williams and Wilkins Company, 1948.

Gray, H. F. R. S. Anatomia. $29^{\mathrm{a}}$ ed. Rio de Janeiro, Guanabara Koogan, 1977.

Harvie, P.; Patel, N. \& Ostlere, S. J. Ulnar nerve compression at Guyon's canal by an anomalous abductor digiti minimi muscle: the role of ultrasound in clinical diagnosis. Hand Surg., 8(2):271-5, 2003.

Harvie, P.; Patel, N. \& Ostlere, S. J. Prevalence and epidemiological variation of anomalous muscles at Guyon's canal. J. Hand Surg., [Br] 29(1):26-9, 2004.

Lockhart, R. D.; Hamilton, G. F. \& Fyfe, F. W. Anatomia do Corpo Humano. $2^{\mathrm{a}}$ ed. Rio de Janeiro, Guanabara Koogan, 1983.

Murata, K.; Tamai, M. \& Gupta, A. Anatomic study of variations of hypothenar muscles and arborization patterns of the ulnar nerve in the hand. J. Hand Surg. [Am]., 29(3):500-9. 2004.
Neto, H. S.; De Carvalho, V. C. \& Penteado, C. V. Morphological And Architetural Aspects Of The Abductor Digiti Minimi. Okajimas Folia Anat. 60(6):389-400, 1984.

Netscher, D. \& Cohen, V. Ulnar nerve compression at the wirst secondary to anomalous muscles: a patient with a variant of abductor digiti minimi. Ann. Plast. Surg., 39(6):647-51. 1997.

Sañudo, J. R.; Mirapeix R. M. \& Ferreira, B. A rare anomaly of abductor digiti minimi. J. anat., 182:439-42. 1993.

Testut L. Traité d'anatomie humanie. $6^{\mathrm{a}}$ ed. Paris. Octave Doin et Fils Editeurs, 1911. V. 1.

Testut, L. \& Latarjet, A. Tratado de Anatomía Humana. $9^{\mathrm{a}}$ ed. Barcelona, Salvat, 1959.

Williams, P. L.; Warwick, R.; Dyson, M. \& Bannister, L. H. Gray Anatomia. $37^{\mathrm{a}}$ ed. Rio de Janeiro, Guanabara Koogan, 1995.

Woodburne, R. T. Anatomia Humana. $6^{\mathrm{a}}$ ed. Rio de Janeiro, Guanabara Koogan, 1984.
Correspondence to:

Prof. Dr. Luiz Carlos Buarque de Gusmão

Condominio Aldebaran Alfa,

Quadra F, № $\mathfrak{0}$ 08, Tabuleiro dos Martins

CEP: $57080-900$

Maceio - Alagoas

BRASIL

Phone number: 031 (082) 3585931
Received: 05-08-2005

Accepted: 14-10-2005 